\title{
Influence of mare, stallion, dose and interval on post-insemination uterine neutrophil counts
}

\author{
John R. Newcombe and Gary M. Kelly \\ Equine Fertility Clinic, Warren House Veterinary Centre, Brownhills, UK
}

\begin{abstract}
Summary: Approximately 2000 inseminations of Warmblood and Irish Draught mares were made with either chilled/transported semen, frozen/thawed semen, freshly collected semen or with seminal plasma recovered after centrifugation of fresh semen. Warm saline was infused via an embryo transfer catheter at intervals of between 1.5 and 24 hours after insemination. Only one flush was performed per oestrus. The saline recovered was diluted 3 parts to one of polychrome methylene blue. Neutrophil counts were made by haemocytometer from two of the large squares (32 small squares) from which the total numbers of neutrophils present in the uterus at that time could be calculated. The limit of sensitivity of the assay was 20 million cells/litre ( 1 cell in 4 large squares). In two separate studies (unpublished) no difference in the neutrophilic reaction was found between stallions or dose. It was therefore considered possible to pool the data from the semen of all the different commercial stallions used.
\end{abstract}

Keywords: insemination / Post Breeding Endometritis / stallion / endometrium / mare / endometritis / reproduction

Einfluss von Stute, Hengst, Dosis und Intervall auf die Anzahl uteriner neutrophiler Granulozyten nach der Insemination

Bei ca. 2000 Warmblut- und Irish Draught-Stuten wurden Besamungen durchgeführt. Verwendung fand gekühltes und transportiertes Sperma, gefrorener und aufgetauter Samen, frisch gewonnenes Sperma oder Seminalplasma, das nach Zentrifugation von Frischsamen gewonnen wurde. Über einen Embryotransferkatheter wurde warme Kochsalzlösung in Abständen zwischen 1,5 und 24 Stunden nach der Besamung infundiert. Pro Rosse wurde nur eine Spülung durchgeführt. Die zurückgewonnene Kochsalzlösung wurde 3 zu 1 mit polychromen Methylenblau verdünnt. Die Anzahl der neutrophilen Granulozyten wurde mittels Hämocytometer ermittelt, indem aus zwei großen Quadraten (32 kleine Quadrate), die Gesamtzahl der zu diesem Zeitpunkt in der Gebärmutter vorhandenen neutrophilen Granulozyten berechnet werden konnte. Die Empfindlichkeitsgrenze des Tests betrug 20 Millionen Zellen pro Liter (1 Zelle in 4 großen Quadraten). In zwei weiteren Studien (unveröffentlicht) wurde kein Unterschied zwischen der Neutrophilenreaktion und den Hengsten oder der Dosis gefunden. Es wird der Schluss gezogen, dass es möglich ist, die Daten von Sperma der verschiedenen im Deckgeschäft befindlichen Hengste zusammenzufassen.

Schlüsselwörter: Besamung / Post Breeding Endometritis / Hengst / Endometrium / Stute / Endometritis / Reproduktion

Citation: Newcombe J. R., Kelly G. M. (2016) Influence of mare, stallion, dose and interval on post-insemination uterine neutrophil counts. Pferdeheilkunde 32, 26-28

Correspondence: John R. Newcombe, Equine Fertility Clinic, Warren House Veterinary Centre, Brownhills WS8 6LS, UK; E-mail: john@warrenhousevets.com

\section{Introduction}

It is well recognised that the equine endometrium reacts to the presence of sperm and other substances introduced at insemination by the secretion fluid containing neutrophilic polymorphic leucocytes. The degree of this acute inflammatory reaction appears to vary between mares and types of insemination. It is assumed thathis reaction although normal, may be antagonistic to fertility when excessive.

Post-insemination, uterine large volume lavage is frequently performed with the view to increasing fertility. Little evidence exists whether this is effective, let alone when is the optimum time. Since most sperm have left the uterus by 2.5 hours (Katila et al 2000) or by $4 \mathrm{~h}$ (Katila 1995), the general assumption is that the removal by flushing, of foreign material including dead or non-viable sperm soon after insemination will reduce the inflammatory reaction, or alternatively when performed later, remove the products of inflamation. The inflamatory reaction is said to peak at $8 \mathrm{~h}$ after $\mathrm{Al}$ (Katila 1995). It has been shown that inflammatory fluid remaining in dioestrus has a negative effect on both pregnancy and pregnancy loss rates (Newcombe 1997). The use of corticost- eroids at insemination has also been shown to mdulate the inflammatory response and to improve pregnancy rate (Bucca et al 2008).

This study was designed to investigate, using clinical material, the effect of interval and of the type of semen used, on the degree of inflammatory reaction as measured by the uterine neutrophil content at different intervals from insemination to lavage.

\section{Materials and methods}

The mares used were of mixed breeding but predominantly Warmbloods and Irish Draught. They were visiting or resident at a commercial Al and ET clinic during the years 2011-2015. Inseminations were made with either chilled/ transported semen, frozen/thawed semen, freshly collected semen or with seminal plasma recovered after centrifugation of fresh semen at $1000 \mathrm{~g}$ for 20 minutes. Warm saline was infused via an embryo transfer catheter at intervals of between 1.5 and 24 
hours after natural cover or insemination. Only one flush was performed per oestrus. The saline recovered was diluted 3 parts to one of polychrome methylene blue and transferred to a haemocytometer. Neutrophil counts were made from two of the large squares (32 small squares) from which the total numbers of neutrophils present in the uterus at that time could be calculated. When very few cells were present, more than 2 of the large squares were counted. The limit of sensitivity of the assay was 20 million ( 1 cell in 4 large squares).

In a separate study (unpublished) using only the semen from one of two stallions (natural cover or fresh insemination), counts were made at the same intervals in the same mares at different oestrous periods. No difference in the neutrophilic reaction was found between the two stallions.

In another separate study (unpublished), counts were made after insemination with frozen semen from 4 different stallions in the same 4 mares at the same intervals. No effect of stallion or dose (number of straws) was found. It was therefore considered possible to pool the data from the semen of all the different commercial stallions used.

\section{Results}

Counts were made from flushes taken at intervals of $1.5,2$, $2.5,3,4,5,6,7,8,9,10,12$, or 24 hours after insemination (Figure 1).Cell counts (no. cells in 32 squares) in individual

Median Uterine WBC vs Time for Different insemination types

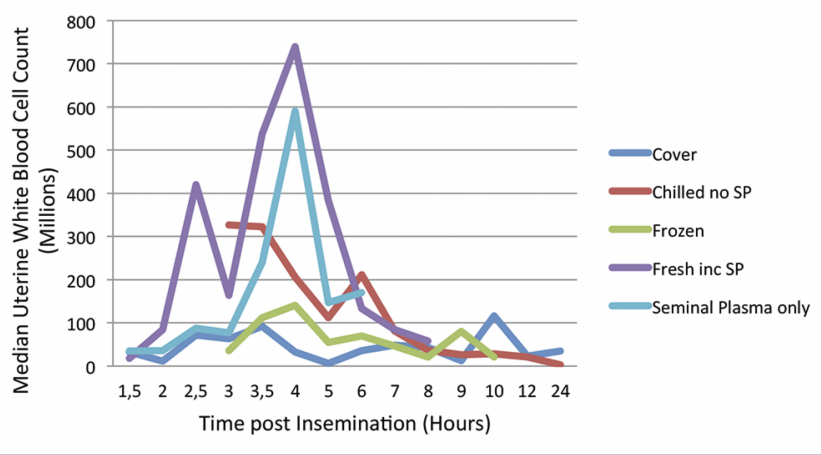

Fig. 1 Change in post-insemination uterine neutrophil count vs. time. Anzahl der uterinen neutrophilen Granulozyten in Abhängigkeit von der Zeit nach Insemination

mares varied from 0 to 2160 following natural cover, from 0 to 2895 following chilled semen, from 0 to 3150 following frozen/thawed semen, from 0 to 3200 following fresh semen and from 0 to 1140 following sperm cell free seminal plasma. Overall, the least inflammatory reaction was seen after natural cover and the most violent reaction, including tissue sloughing, was seen following chilled and frozen/thawed semen. Significant differences in the median counts between natural cover and fresh semen were seen at all intervals from 2.5 to 6 hours inclusive. Fresh semen counts were approximately $\times 6, \times 5, \times 6, \times 22, \times 50$ and $\times 4$ higher than cover at $2.5,3,4,5$, and 6 hours respectively. Chilled semen counts were approximately $\times 5, \times 3, \times 6, \times 19$ and $\times 6$ higher than cover at 3 to 6 hours inclusive. Cover was $\times 4$ higher than chilled at 10 hours.
Frozen semen counts were approximately $\times 4$ and $\times 10$ higher than cover at 4 and 5 hours. Cover was $\times 5$ higher than frozen at 10 hours. Seminal plasma counts were $\times 8, \times 100$, $\times 4, \times 3$ and $\times 10$ higher than cover at $4,5,6,7$ and 12 hours respectively.

Chilled semen counts were $\times 9, \times 3$, and $\times 3$ higher than frozen semen at $3,3.5$ and 6 h respectively. Fresh semen counts were $\times 11, \times 2, \times 7$ and $\times 3$ higher than seminal plasma at $2.5,3,3.5$ and 4 hours respectively. Data was also divided into quartiles. Differences in the mean counts between cover and fresh semen were seen in the first quartile at 2, 2.5, 4 and 6 hours, in the second quartile at 2.5 to 6 hours inclusive, in the third quartile at 2 to 5 hours inclusive and in the fourth quartile at 3 to 5 hours inclusive.

Differences between cover and chilled semen were seen in the first quartile at 3.5 and 4 hours, in the second quartile at 3 to 6 hours inclusive, in the third quartile at 3 to 6 hours inclusive and in the fourth quartile at 4 hours. Difference between cover and frozen were seen in the first quartile at 4, 5, 7 and 9 hours, in the second quartile at 4 and 5 hours, in the third quartile at 3.5 to 6 hours and in the fourth quartile at 3,4 and 5 hours. Difference between cover and seminal plasma were seen in the first quartile at 3 and 3.5 hours, in the second quartile at 3.5 to 6 hours, in the third quartile at 4 and 5 hours and in the fourth quartile at 4 and 6 hours. Difference between chilled and frozen were seen in the first quartile at 3, 4 and 6 hours, in the second quartile at 3 to 7 hours inclusive, in the third quartile at 3 to 6 hours inclusive and in the fourth quartile at 3, 3.5 and 5 hours. Differences between fresh semen and seminal plasma were seen in the first quartile at only 2 hours, in the second quartile at 2 to 3.5 hours, in the third quartile at 2 to 5 hours and in the fourth quartile at 3 to 5 hours.

\section{Discussion}

The severity of the inflammatory reaction to chilled and frozen semen was surprising, especially when compared with natural cover. Kotilainen and others (1994) showed that the uterine response at $6 \mathrm{~h}$ is higher for concentrated sperm samples than when diluted. The highest cell counts were often accompanied by endometrial tissue sloughing and bloody fluid although many of these mares still became pregnant. However this reaction declined rapidly and by 6 hours although endometrial tissue was often found in the vagina, the cell content of the uterine lumen had declined. It was proposed that the difference was due to the absence of seminal plasma in chilled and frozen semen. Troedsson and others (1995) showed that seminal plasma inhibits complement activation and suppresses neutrophil chemotaxis and sperm phagocytosis. Suppression of neutrophil influx may temporarily protect sperm from phagocytosis (Troedsson 1999). However when seminal plasma alone was inseminated, the counts were higher than cover at all intervals from 3.5 hours onwards. Was this due to the presence of substances released from sperm damaged during centrifugation? The other surprising result was the extreme difference in counts found between cover and freshly inseminated semen which still included seminal plasma. This was in contrast to the findings of Kotilainen (1994.) Counts following fresh semen were significantly higher at all intervals 
from 2 to 6 hours. Peak count of 750 (at 4 hours) was higher even than after chilled semen. While the count had no correlation with the volume of fresh semen inseminated (from 6 to $35 \mathrm{ml}$ ), it would seem that the physical act of copulation was a major factor. Could this have involved oxytocin release (Madill et al 2000) aiding earlier uterine clearance or the known presence of oxytocin in the gel fraction (Watson et al 1999)? This study is still ongoing and hopefully will eventually have the answers to some of these surprising results.

\section{References}

Bucca S., Carli A., Buckley T., Dolci G., Fogarty U. (2008) The use of dexamethasone administration to mares at breeding time in the modulation of persistent mating induced endometritis. Theriogenology 70, 1093-1100

Katila T. (1995) Onset and duration of uterine inflammatory response of mares after insemination with fresh semen. Biol. Reprod. Monogr. 1, 515-517
Katila T., Sankari S., Makela O. (2000) Transport of spermatozoa in the reproductive tracts of mares. J. Reprod.Fert. Suppl. 56,571-578

Newcombe J. R. (1997) The effect of the incidence and depth of intra-uterine fluid in early dioestrus on pregnancy rate in mares. Pferdeheilkunde 1, 545

Kotilainen T., Huhtinen M., Katila K. (1994) Sperm induced leucocytosis in the equine uterus. Theriogenology 41, 629-636

Madill S., Troedsson M. H. T., Alexander S. L., Shand N., Santschi E. M., Irvine C. H. G. (2000) Simultaneous recording of pituitary oxytocin secretion and myometrial activity in oestrous mares exposed to various breeding stimuli. J. Reprod. Fert. 56 (Suppl.), 351-361

Troedsson M. H. T., Steiger B. M., Ibrahim M. N., King VL, Foster D. N., Crobo B. G. (1995) Mechansm of sperm induced endometritis in mares. Biol. Reprod. 52 (Suppl. 1), 507

Troedsson M. H. T., Franklin R. K., Croba B. G. (1999) Suppression of PMN-chemotaxis by different molecular weight fractions of equine plasma. Pferdeheilkunde 15, 568-573

Watson E. D., Nikolakopoulos E., Gilbert E., Goode J. (1999). Oxytocin in the semen and gonads of the stallion. Theriogenology 51 , 855-865 